\title{
PENGARUH TIPE KEPRIBADIAN DAN RELIGIUSITAS TERHADAP SUBJECTIVE WELL BEING PADA WANITA YANG BERPERAN GANDA DI JAKARTA
}

\author{
Chintya Eka Dewi \\ UIN Syarif Hidayatullah \\ Jakarta \\ chintyaekadewi@gmail.com
}

\author{
Ima Sri Rahmani \\ Himpunan Psikologi \\ Indonesia \\ ima.rahmani@uinjkt.ac.id
}

\begin{abstract}
The aim of this study is to determine the predictor variable for subjective well being as dependent variable of woman with multiple roles. Two independent variables, namely personalitiy and religiousity, are used in order to determine which one of these two independent variables would be the best predictor for "subjective well being." As a quantitative research, the multiple regression analysis is used to measure 200 respondents working at some companies located in North Jakarta and Central Jakarta. Scale measurement is modified from the original scale constructed by Diener et.al (1985) for Subjective Well Being Scale, Watson et.al (1988) for Personality Scale and Lewis Goldberg (1992), Fetzer Institute (1999) for Religiousity for our own research. There is a significant influence that personality and religiousity could be a predictif factor to measure „a subjective well being" of woman with multiple role. Dimension measured for the variable of personality here are agreebleness, conscientiousness, and openess to experience, while for religiousity: private religious practice, religious/spiritual history, and organizational religiousness.
\end{abstract}

Kata Kunci: Subjective Well Being, Type of Personality, Religiousity, Woman With Multiple Role

\begin{abstract}
Abstrak
Tujuan dari penelitian ini adalah untuk menentukan prediktor variable untuk subjective well-being sebagai variabel dependen dari wanita yang berperan ganda. Dua variabel independen, yaitu kepribadian dan religiusitas, digunakan untuk menentukan prediktor terbaik diantara dua variabel independen untuk subjective well-being. Sebagai penelitian kuantitatif, analisis multiple regresi digunakan untuk mengukur 200 responden yang bekerja di beberapa perusahaan yang berlokasi ini Jakarta Utara dan Jakarta Pusat. Pengukuran skala di modifikasi dari skala asli yang dibuat oleh Diener et.al (1985) untuk skala subjective well-being, skala kepribadian dari Watson et.al (1988) dan Lewis Goldberg (1992), dan institusi Fetzer untuk skala religiusitas untuk kepentingan penelitian. Terdapat pengaruh yang signifikan bahwa kepribadian dan religiusitas dapat menjadi prediktor untuk mengukur subjective well-being dari wanita yang berperan ganda. Dimensi yang diukur untuk variabel kepribadian adalah agreeableness, conscientiousness, dan openess to experience, sedangkan religiusitas mencakup: ritual agama secara privat, sejarah agama dan spiritual, dan organisasi keberagamaan.
\end{abstract}


Keywords: Religiusitas, Subjective Well-Being, Tipe Kepribadian, Wanita yang Berperan Ganda

Diterima: 2 November 2014 2014

Disetujui: 7 Desember 2014

Direvisi: 29 November 


\section{PENDAHULUAN}

Semua individu menginginkan kebahagiaan dalam hidupnya. Setiap individu juga memiliki harapan-harapan yang ingin dicapai guna pemenuhan kepuasan dalam kehidupannya. Kebahagiaan dan kepuasan dalam hidup merupakan bagian dari konsep kesejahteraan subjektif yang mencakup aspek afektif dan kognitif manusia. Menurut Diener, Scollon, dan Lucas (2003) kesejahteraan subjektif (subjective well being) merupakan kategori yang luas mengenai fenomena yang menyangkut respon-respon emosional individu, domain kepuasan dan penilaian-penilaian global atas kepuasan hidup. Kondisi ini juga diharapkan oleh wanita yang harus berperan ganda dalam menjalani kehidupannya.

Dewasa ini, fenomena meningkatnya jumlah wanita yang memiliki peran ganda baik sebagai istri, ibu, dan pekerja mulai menjadi sebuah fenomena global. Maclean (2004) menyatakan bahwa pengaruh peran ganda pada subjective well-being wanita yang berperan ganda masih kontroversial, belum jelas diketahui apakah pengaruh tersebut menguntungkan atau merugikan. Oleh sebab itu, merupakan hal yang sangat menarik untuk dilakukan penelitian guna mengetahui bagaimana kondisi subjective well-being wanita dengan peran ganda yang diembannya.

Kehidupan wanita yang berperan ganda penuh dinamika tersendiri. Hal ini dapat mempengaruhi mereka dalam merasakan kebahagiaan. Alan Carr (2004) mengatakan bahwa kebahagiaan dapat disetarakan dengan istilah subjective wellbeing. Menurut pendapat Diener, Lucas dan Oishi (1999) subjective well-being adalah evaluasi individu terhadap pengalaman hidupnya, yang terdiri dari evaluasi kognitif dan afektif terhadap hidup.

Faktor-faktor yang mempengaruhi subjective well being antara lain adalah kepribadian, kesehatan, pendapatan, religiusitas, pernikahan, usia, gender, job morale, pendidikan, kecerdasan (Diener et al., 1999). Penelitian yang dilakukan Diener, Lucas dan Oishi (2005) menunjukkan bahwa kepribadian merupakan salah satu prediktor subjective well being yang paling konsisten.

Oleh karena itu, variabel kepribadian menjadi salah satu variabel yang akan dikaji di dalam penelitian ini. Teori kepribadian yang akan digunakan pada penelitian ini adalah 
tipe kepribadian Big Five, yaitu suatu pendekatan yang digunakan dalam psikologi untuk melihat kepribadian manusia melalui trait yang tersusun dalam lima buah domain. Lima trait

84 
kepribadian tersebut adalah agreebleness, conscientiousness, extraversion, neuroticism, dan openess to experiences (Pervin, Cervone, \& John, 2010).

Selain kepribadian, religiusitas juga mempunyai pengaruh yang signifikan terhadap subjective well being. Fetzer Institute (1999) mengatakan bahwa religiusitas adalah sistem peribadatan dan doktrin yang ada pada suatu kelompok, yang bersifat behavioural (perilaku), social (sosial), dan doktrinal (kedoktrinan) dan penginternalisasian sifat-sifat tertentu.Fetzer Institute (1999) menyebutkan bahwa ada duabelas dimensi religiusitas, yaitu daily spiritual experience (pengalaman spiritual sehari-hari), religion meaning (kebermaknaan hidup), value (nilai-nilai agama), belief (keyakinan),forgiveness (memaafkan), private religious practice (praktek ibadah individu), religious coping (penggunaan religiusitas/spritual sebagai coping), religious support (dukungan antar umat seagama), religious/spiritual history (sejarah keberagamaan), commitment (komitmen beragama), organizational religiousness (organisasi atau kegiatan keagamaan), dan religious preference (identifikasi agama).

Terdapat berbagai hasil penelitian yang mengalami kontradiksi. Oleh sebab itu, selain dinamika faktor penentu subjective well-being, kontradiktif temuan hasil penelitian juga melatarbelakangi gagasan dilakukannya penelitian ini. Terlebih lagi, ternyata hanya sedikit penelitian yang membahas subjective well-being wanita berperan ganda yang tidak bersuami atau single parent dan wanita berperan ganda yang bersuami untuk konteks di Indonesia. Maka, berdasarkan berbagai penjelasan yang telah diuraikan, serta berdasarkan perbedaan temuan hasil penelitian yang telah dijabarkan di atas, dapat disimpulkan bahwa fokus penelitian ini adalah tipe kepribadian dan religiusitas terhadap subjective well-being wanita berperan ganda, khususnya pada wanita berperan ganda tidak bersuami atau single parent dan wanita berperan ganda bersuami.

\section{METODE}

Populasi dalam penelitian ini adalah wanita berperan ganda di wilayah Jakarta Utara dan Jakarta Pusat berjumlah 200 orang. Teknik pengambilan samel yang digunakan adalah nonprobability sampling, yaitu dengan purposive sampling di 
mana sampel yang diambil adalah sampel yang memiliki ciriciri spesifik yang telah peneliti tentukan (Moleong, 2008). Instrumen pengumpulan data yang digunakan dalam penelitian ini berbentuk kuesioner dengan menggunakan skala model Likert yang telah 
diadaptasi dan dimodifikasi menjadi empat alternatif pilihan jawaban yakni, sangat sesuai, sesuai, tidak sesuai dan sangat tidak sesuai. Instrumen pengumpulan data dalam penelitian ini menggunakan tiga skala, yaitu skala subjective well-being, skala kepribadian, dan skala religiusitas.

\section{Skala Subjective Well-Being}

Skala subjective well-being adalah skala yang digunakan untuk mengukur persepsi individu terhadap pengalaman hidupnya, yang terdiri dari evaluasi kognitif dan afektif, yaitu:

1. Untuk mengukur evaluasi kognitif yaitu nilai kepuasan hidup individu secara global, penulis menggunakan Satisfaction with Life Scale (SWLS) yang dikembangkan oleh Diener et al. (1985). Satisfaction with Life Scale (SWLS) terdiri dari lima item dan menggunakan skala likert dengan tujuh rentangan skala, namun dalam pengadaptasiannya penulis mengubah rentangan skala tujuh menjadi rentangan skala empat, yaitu "sangat tidak sesuai", "tidak sesuai", "sesuai", dan "sangat sesuai", agar tidak ada kecenderungan jawaban pada skala di tengah-tengah atau ragu-ragu. Setelah dilakukan uji validitas konstruk dengan menggunakan Confirmatory Factor Analysis (CFA) diperoleh model fit dengan chi-square $=3.04, \mathrm{df}=3$, P-value $=0.38560$, RMSEA $=0.008$.

2. Penulis juga menggunakan Positive Affect Negative Schedule (PANAS) yang dikembangkan oleh Watson et al. (1988) untuk mengukur evaluasi afektif individu. Positive Affect Negative Schedule (PANAS) merupakan skala yang digunakan untuk mengukur tingkat terjadinya afek positif dan afek negatif dalam satu waktu dengan menggunakan skala likert, dan terdiri dari 10 afek positif dan 10 afek negatif. Skala ini menggunakan skala likert dengan empat rentangan skala, yaitu "tidak pernah", "jarang", "sering", dan "sangat sering". Setelah dilakukan uji validitas konstruk dengan menggunakan Confirmatory Factor Analysis (CFA) diperoleh model fit dengan chi-square

$=36.92, \mathrm{df}=25, P$-value $=0.05869$, RMSEA $=0.049$ pada afek positif, dan model fit dengan chi-square $=8.16$, $\mathrm{df}=15$, $P$-value $=0.91702$, RMSEA $=0.000$ pada afek negatif.

\section{Skala Kepribadian}

Peneliti menggunakan alat ukur baku International Personality Item Pool (IPIP), dikembangkan oleh Lewis Goldberg (1992) dan 
telah diterjemahkan ke dalam bahasa Indonesia oleh penulis. Skala ini terdiri 100 item

86 
pernyataan yang diukur dengan menggunakan empat rentangan dalam skala likert, yaitu "sangat tidak sesuai", "tidak sesuai", "sesuai", dan "sangat sesuai".

Skala ini memiliki lima dimensi, yaitu neuroticism, extraversion, agreebleness, openess to experiences, dan conscientiousness. Dimana tiap dimensi terdiri dari 20 item. Setelah dilakukan uji validitas konstruk dengan menggunakan Confirmatory Factor Analysis (CFA) diperoleh model fit dengan chi-square $=72.46, \mathrm{df}=57, P$-value $=0.08145$, RMSEA $=$ 0.037 pada neuroticism, diperoleh model fit dengan chi-square $=56.63, \mathrm{df}=44, P$-value $=0.09594, \mathrm{RMSEA}=0.038$ pada extraversion, diperoleh model fit dengan chi-square $=112.89$, $\mathrm{df}=92, \quad P$-value $=0.06877$, RMSEA $=0.034$ pada agreeableness, diperoleh model fit dengan chi-square $=$ 128.19, $\mathrm{df}=106$, -value $=0.07022$, RMSEA $=0.032$ pada openess to experiences, dan diperoleh model fit dengan chisquare $=65.50, \mathrm{df}=51, P$-value $=0.08331, \mathrm{RMSEA}=0.038$ pada conscientiousness.

\section{Skala Religiusitas}

Peneliti menggunakan adaptasi dan modofikasi dari skala religiusitas Brief Multidimensional Measure of Religiousness dari Fetzer Institute (1999) berdasarkan buku "Multidimensional Measurement of Religiousness/ Spirituality for Use in Health Research". Skala ini terdiri 78 item pernyataan yang diukur dengan menggunakan empat rentangan dalam skala likert, yaitu "sangat tidak sesuai", "tidak sesuai", "sesuai", dan "sangat sesuai".

Setelah dilakukan uji validitas konstruk dengan menggunakan Confirmatory Factor Analysis (CFA) diperoleh model fit dengan chi-square $=810.21$, df $=752, P$-value $=$ 0.06929 , RMSEA $=0.020$.

Untuk melihat pengaruh independent variable yang diteliti yaitu tipe kepribadian (neuroticism, extraversion, openess to experience, agreeableness, dan conscientiousness) dan religiusitas (daily spiritual experience, religion meaning, value, belief, forgiveness, private religious practice, religious coping, religious support, religious/spiritual history, commitment, organizational religiusness, serta religious preference) terhadap subjective well-being pada wanita berperan ganda, peneliti menggunakan teknik statistik analisis regresi berganda (multiple regression analysis). 


\section{HASIL}

\section{Gambaran Deskriptif Sampel}

Sampel dalam penelitian ini sebanyak 400 orang yang terdiri dari 100 wanita berperan ganda yang tidak bersuami atau single parent dan 100 wanita berperan ganda bersuami dengan rentang usia antara 25 sampai 50 tahun.

\section{Hasil Uji}

Langkah pertama peneliti melihat besaran $\mathrm{R}$ square untuk mengetahui berapa persen (\%) varians DV yang dijelaskan oleh IV seperti yang dijelaskan tabel 1.0 di bawah ini.

Tabel 1

Model Summary $R$

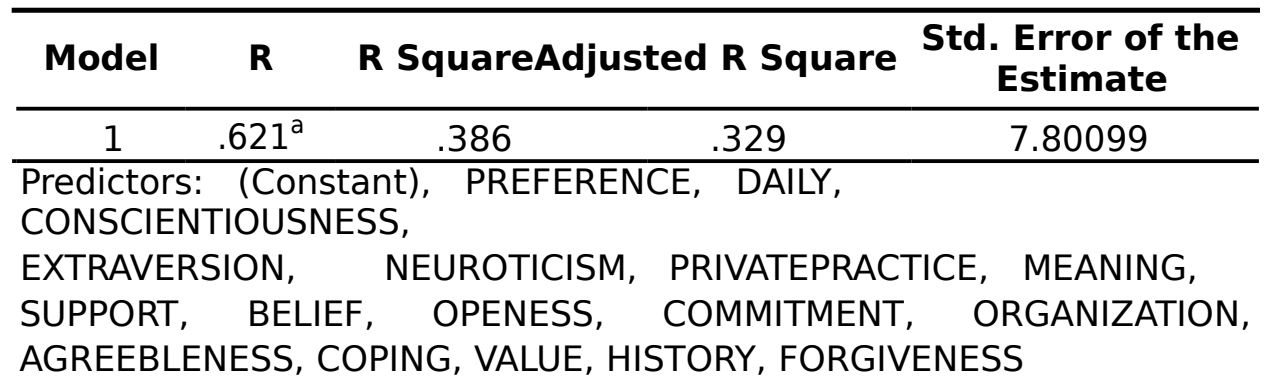

Dari tabel 1 , dapat dilihat bahwa perolehan $R$-square sebesar 0.386 atau $38.6 \%$. Artinya proporsi varians dari subjective well being wanita yang berperan ganda yang dapat dijelaskan oleh semua independent variable adalah sebesar $38.6 \%$, sisanya, $61.4 \%$ dipengaruhi oleh variabel lain yang tidak ikut diukur dalam penelitian ini. Langkah kedua peneliti menganalisis dampak dari seluruh independent variable terhadap subjective well being wanita yang berperan ganda. Adapun hasil uji $\mathrm{F}$ dapat dilihat pada tabel 2.0 di bawah ini.

Tabel 2

Anova seluruh IV Terhadap DV

\begin{tabular}{|c|c|c|c|c|c|c|}
\hline \multicolumn{2}{|c|}{ Model } & \multirow{2}{*}{$\begin{array}{l}\begin{array}{l}\text { Sum of } \\
\text { Squares }\end{array} \\
6962.485\end{array}$} & \multirow{2}{*}{$\frac{\text { Df }}{17}$} & \multirow{2}{*}{$\begin{array}{l}\begin{array}{l}\text { Mean } \\
\text { Square }\end{array} \\
409.558\end{array}$} & \multirow{2}{*}{$\frac{\mathbf{F}}{6.730}$} & \multirow{2}{*}{$\frac{\text { Sig. }}{.000^{\mathrm{a}}}$} \\
\hline 1 & Reg & & & & & \\
\hline & Res & 11075.682 & 182 & 60.855 & & \\
\hline & Total & 18038.167 & 199 & & & \\
\hline
\end{tabular}


88 
Jika dilihat pada bagian kolom sig, dapat diketahui nilai ( $p$ $<0.05$ ), maka hipotesis nol ditolak. Oleh karena itu hipotesis nihil mayor yang menyatakan bahwa tidak terdapat pengaruh signifikan dari variabel tipe kepribadian (agreebleness, conscientiousness, extraversion, neuroticism, dan openess to experiences) serta variabel religiusitas (daily spiritual experiencereligion, religion meaning, value, belief, forgiveness, private religious practice, religious coping, religious support, religious/ spiritual history, commitment, organizational religiousness, dan religious preference) terhadap variabel subjective well being wanita yang berperan ganda ditolak.

Langkah ketiga, setelah diketahui bahwa hipotesis alternatif diterima. Selanjutnya melihat signifikan atau tidaknya koefisien regresi dari masing-masing independent variable seperti hasil koefisien regresi yang tertera pada tabel 3.

Tabel 3

Koefisien Regresi

\begin{tabular}{|c|c|c|c|c|}
\hline \multicolumn{5}{|c|}{ Coefficients $^{\mathrm{a}}$} \\
\hline \multirow{3}{*}{ Model } & Unstand & $\begin{array}{r}\text { ize } \\
\text { d }\end{array}$ & \multirow{3}{*}{$\begin{array}{c}\text { Standardized } \\
\text { Coefficients } \\
\text { Beta }\end{array}$} & \multirow{3}{*}{ Sig } \\
\hline & Coeffic & & & \\
\hline & B & $\begin{array}{l}\text { Std. } \\
\text { Error }\end{array}$ & & \\
\hline (Constant) & 11.401 & 6.717 & & 091 \\
\hline AGREEBLENESS & -.295 & .082 & -.280 & 000 \\
\hline CONSCIENTIOUSNESS & .208 & .075 & .197 & 006 \\
\hline EXTRAVERSION & .056 & .082 & .052 & 492 \\
\hline NEUROTICISM & -.017 & .057 & -.018 & 759 \\
\hline OPENESS & .256 & .086 & .245 & 003 \\
\hline DAILY & .102 & .086 & .096 & 236 \\
\hline MEANING & -.056 & .072 & -.059 & 434 \\
\hline 1 VALUE & -.036 & .083 & -.037 & 671 \\
\hline BELIEF & .116 & .078 & .122 & 141 \\
\hline FORGIVENESS & .020 & .071 & .021 & 775 \\
\hline PRIVATEPRACTICE & -.259 & .085 & -.212 & 003 \\
\hline
\end{tabular}




\begin{tabular}{lcccc} 
COPING & .112 & .094 & .094 & 237 \\
SUPPORT & .043 & .074 & .045 & 562 \\
HISTORY & .186 & .079 & .195 & 019 \\
COMMITMENT & .023 & .082 & .024 & 779 \\
ORGANIZATION & .243 & .070 & .255 & 001 \\
PREFERENCE & .070 & .082 & .074 & 390 \\
\hline
\end{tabular}

8

9 
Berdasarkan tabel 3 di atas, dapat disimpulkan persamaan regresinya sebagai berikut:

\section{Subjective well being pada wanita yang berperan ganda} $=(11.401)+(-0.295) \quad$ Agreebleness $*+0.208$ Conscientiousness* +0.056 Extraversion $+(-0.017)$ Neuroticism +0.256 Openess to experiences* +0.102 Daily spiritual experience $+(-0.056)$ Religion meaning $+(-0.036)$ Value +0.116 Belief +0.020 Forgiveness + $(-0.259)$ Private religious practice* +0.112 Religious coping + 0.043 Religious support +0.186 Religious/ spiritual history* + 0.023 Commitment +0.243 Organizational religiousness* + 0.070 Religious preference.

Untuk melihat signifikan atau tidaknya koefisien regresi yang dihasilkan dapat dilihat pada nilai sig pada kolom di atas, jika sig < 0.05 maka koefisien regresi yang dihasilkan signifikan pengaruhnya terhadap subjective well being wanita yang berperan ganda dan sebaliknya. Dari hasil di atas terdapat enam koefisien regresi yang signifikan pengaruhnya terhadap subjective well being wanita yang berperan ganda, agreeableness, conscientiousness, openess to experiencess, private religious practice, religious/ spiritual history, dan organizational religiousness, sedangkan sisanya tidak signifikan. Hal ini menyatakan hanya enam independent variable (IV) dari 17 variabel yang signifikan. Penjelasan dari nilai koefisien regresi yang diperoleh pada masing-masing independent variable (IV) adalah sebagai berikut:

1. Variabel agreebleness: diperoleh nilai koefisiensi regresi sebesar -0.295 dengan signifikansi 0.000 (sig < 0.05), yang berarti bahwa variabel agreebleness berpengaruh secara signifikan dan negatif terhadap subjective well being pada wanita yang berperan ganda. Artinya semakin tinggi agreebleness maka semakin rendah subjective well being pada wanita yang berperan ganda.

2. Variabel conscientiousness: diperoleh nilai koefisiensi regresi sebesar 0.208 dengan signifikansi 0.006 (sig < 0.05), yang berarti bahwa variabel conscientiousness berpengaruh secara signifikan dan positif terhadap subjective well being pada wanita yang berperan ganda. Artinya semakin tinggi conscientiousness maka semakin tinggi pula subjective well being pada wanita yang berperan ganda. 
3. Variabel extraversion: diperoleh nilai koefisiensi regresi sebesar 0.056 dengan signifikansi 0.492 ( $\operatorname{sig}>0.05$ ), yang berarti bahwa variabel extraversion tidak berpengaruh secara signifikan terhadap subjective well being pada wanita yang berperan ganda.

90 
4. Variabel neuroticism: diperoleh nilai koefisiensi regresi sebesar -0.017 dengan signifikansi 0.759 ( sig $>0.05$ ), yang berarti bahwa variabel neuroticism tidak berpengaruh secara signifikan terhadap subjective well being pada wanita yang berperan ganda.

5. Variabel openess to experiences: diperoleh nilai koefisiensi regresi sebesar 0.256 dengan signifikansi 0.003 (sig < 0.05), yang berarti bahwa variabel openes to experiences berpengaruh secara signifikan dan positif terhadap subjective well being pada wanita yang berperan ganda. Artinya semakin tinggi openess to experiences maka semakin tinggi pula subjective well being pada wanita yang berperan ganda.

6. Variabel daily spiritual experience: diperoleh nilai koefisiensi regresi sebesar 0.102 dengan signifikansi 0.236 (sig > 0.05), yang berarti bahwa variabel daily spiritual experience tidak berpengaruh secara signifikan terhadap subjective well being pada wanita yang berperan ganda.

7. Variabel religion meaning: diperoleh nilai koefisiensi regresi sebesar - 0.056 dengan signifikansi 0.434 (sig > 0.05), yang berarti bahwa variabel religion meaning tidak berpengaruh secara signifikan terhadap subjective well being pada wanita yang berperan ganda.

8. Variabel value: diperoleh nilai koefisiensi regresi sebesar -0.036 dengan signifikansi 0.671 ( $\mathrm{sig}>0.05$ ), yang berarti bahwa variabel value tidak berpengaruh secara signifikan terhadap subjective well being pada wanita yang berperan ganda.

9. Variabel belief: diperoleh nilai koefisiensi regresi sebesar 0.116 dengan signifikansi 0.141 ( $\operatorname{sig}>0.05$ ), yang berarti bahwa variabel belief tidak berpengaruh secara signifikan terhadap subjective well being pada wanita yang berperan ganda.

10. Variabel forgiveness: diperoleh nilai koefisiensi regresi sebesar 0.020 dengan signifikansi 0.775 (sig > 0.05), yang berarti bahwa variabel forgiveness tidak berpengaruh secara signifikan terhadap subjective well being pada wanita yang berperan ganda.

11. Variabel private religious practice: diperoleh nilai koefisiensi regresi sebesar -0.259 dengan signifikansi 0.003 (sig < $0.05)$, yang berarti bahwa variabel private religious practice berpengaruh secara signifikan dan negatif terhadap 
subjective well being pada wanita yang berperan ganda. Artinya semakin tinggi religious practice maka semakin rendah subjective well being wanita yang berperan ganda.

12. Variabel religious coping: diperoleh nilai koefisiensi regresi sebesar 0.112 dengan signifikansi 0.237 ( $\mathrm{sig}>0.05$ ), yang berarti bahwa variabel

9

1 
religious coping tidak berpengaruh secara signifikan terhadap subjective well being pada wanita yang berperan ganda.

13. Variabel religious support: diperoleh nilai koefisiensi regresi sebesar 0.043 dengan signifikansi 0.562 ( $\mathrm{sig}<0.05$ ), yang berarti bahwa variabel religious support tidak berpengaruh secara signifikan terhadap subjective well being pada wanita yang berperan ganda.

14. Variabel religious/ spiritual history: diperoleh nilai koefisiensi regresi sebesar 0.186 dengan signifikansi 0.019 (sig < 0.05), yang berarti bahwa variabel religious/ spiritual history berpengaruh secara signifikan dan positif terhadap subjective well being pada wanita yang berperan ganda. Artinya semakin tinggi religious/ spiritual history maka semakin tinggi pula subjective well being pada wanita yang berperan ganda.

15. Variabel commitment: diperoleh nilai koefisiensi regresi sebesar 0.023 dengan signifikansi 0.779 ( $\mathrm{sig}>0.05$ ), yang berarti bahwa variabel commitment tidak berpengaruh secara signifikan terhadap subjective well being pada wanita yang berperan ganda.

16. Variabel organizational religiousness: diperoleh nilai koefisiensi regresi sebesar 0.243 dengan signifikansi 0.001 (sig < 0.05), yang berarti bahwa variabel organizational religiousness berpengaruh secara signifikan dan positif terhadap subjective well being pada wanita yang berperan ganda. Artinya semakin tinggi organizational religiousness maka semakin tinggi pula subjective well being pada wanita yang berperan ganda.

17. Variabel religious preference: diperoleh nilai koefisiensi regresi sebesar 0.070 dengan signifikansi 0.390 ( $\mathrm{sig}>$ 0.05), yang berarti bahwa variabel religious preference tidak berpengaruh secara signifikan terhadap subjective well being pada wanita yang berperan ganda.

Kemudian langkah selanjutnya peneliti menguji penambahan proporsi varians dari tiap variabel independen jika IV tersebut dimasukkan satu per satu ke dalam analisis regresi. Besarnya proporsi varians pada ketangguhan mental dapat dilihat pada tabel 4 berikut: 
92 
Tabel 4

Kontribusi Varians Independent Variable Terhadap Dependent Variable

\begin{tabular}{|c|c|c|c|c|c|c|}
\hline Mode & R Square & $\begin{array}{c}\text { R Square } \\
\text { Change }\end{array}$ & $\begin{array}{l}\text { Change } \\
\text { Statistics } \\
\text { F } \\
\text { Change }\end{array}$ & df1 & df2 & $\begin{array}{l}\text { Sig. F } \\
\text { Change }\end{array}$ \\
\hline 1 & .004 & .004 & .870 & 1 & 198 & .352 \\
\hline 2 & .041 & .037 & 7.561 & 1 & 197 & .007 \\
\hline 3 & .056 & .015 & 3.023 & 1 & 196 & .084 \\
\hline 4 & .056 & .000 & .072 & 1 & 195 & .789 \\
\hline 5 & .178 & .121 & 28.652 & 1 & 194 & .000 \\
\hline 6 & .196 & .018 & 4.419 & 1 & 193 & .037 \\
\hline 7 & .198 & .002 & .597 & 1 & 192 & .441 \\
\hline 8 & .210 & .012 & 2.836 & 1 & 191 & .094 \\
\hline 9 & .241 & .031 & 7.761 & 1 & 190 & .006 \\
\hline 10 & .242 & .001 & .170 & 1 & 189 & .681 \\
\hline 11 & .244 & .002 & .442 & 1 & 188 & .507 \\
\hline 12 & .287 & .043 & 11.359 & 1 & 187 & .001 \\
\hline 13 & .295 & .008 & 2.186 & 1 & 186 & .141 \\
\hline 14 & .326 & .030 & 8.325 & 1 & 185 & .004 \\
\hline 15 & .331 & .005 & 1.417 & 1 & 184 & .235 \\
\hline 16 & .383 & .053 & 15.657 & 1 & 183 & .000 \\
\hline 17 & .386 & .003 & .743 & 1 & 182 & .390 \\
\hline
\end{tabular}

Dari tabel di atas didapatkan informasi sebagai berikut:

1. Variabel agreebleness memberikan sumbangan sebesar $0.4 \%$ dalam varian subjective well being pada wanita yang berperan ganda. Sumbangan tersebut tidak signifikan dengan $\mathrm{F}$ change $=0.870, \mathrm{df2}=198$ dan Sig.F Change $=$ 0.352 ( $\operatorname{sig}>0.05$ ).

2. Variabel conscientiousness memberikan sumbangan sebesar $3.7 \%$ dalam varian subjective well being pada wanita yang berperan ganda. Sumbangan tersebut signifikan dengan $F$ change $=7.561$, df2 $=197$ dan Sig. $F$ Change $=0.007($ sig $<0.05)$.

3. Variabel extraversion memberikan sumbangan sebesar $1.5 \%$ dalam varian subjective well being pada wanita yang berperan ganda. Sumbangan tersebut tidak signifikan dengan $\mathrm{F}$ change $=3.023$, df2 $=196$ dan Sig. $F$ Change $=$ 0.084 ( $\operatorname{sig}>0.05$ ). 
4. Variabel neuroticism memberikan sumbangan sebesar $0.0 \%$ dalam varian subjective well being pada wanita yang berperan ganda. 
Sumbangan tersebut tidak signifikan dengan $\mathrm{F}$ change $=$ 0.072 , df2 $=195$ dan Sig.F Change $=0.789$ ( $\operatorname{sig}>0.05)$.

5. Variabel openess to experiences memberikan sumbangan sebesar $12.1 \%$ dalam varian subjective well being pada wanita yang berperan ganda. Sumbangan tersebut signifikan dengan $\mathrm{F}$ change $=28.652$, df2 $=194$ dan Sig. $\mathrm{F}$ Change $=0.000($ sig $<0.05)$.

6. Variabel daily spiritual experience religion memberikan sumbangan sebesar $1.8 \%$ dalam varian subjective well being pada wanita yang berperan ganda. Sumbangan tersebut signifikan dengan Fchange $=4.419$, df2 $=193$ dan Sig. F Change $=0.037(\mathrm{sig}<0.05)$.

7. Variabel religion meanin gmemberikan sumbangan sebesar $0.2 \%$ dalam varian subjective well being pada wanita yang berperan ganda. Sumbangan tersebut tidak signifikan dengan $\mathrm{F}$ change $=0.597$, df2 $=192$ dan Sig. $F$ Change $=$ 0.441 ( $\operatorname{sig}>0.05$ ).

8. Variabel value memberikan sumbangan sebesar $1.2 \%$ dalam varian subjective well being pada wanita yang berperan ganda. Sumbangan tersebut tidak signifikan dengan $\mathrm{F}$ change $=2.836$, df2 $=191$ dan Sig. $F$ Change $=$ 0.094 ( $\operatorname{sig}>0.05$ ).

9. Variabel belief memberikan sumbangan sebesar $3.1 \%$ dalam variansubjective well being pada wanita yang berperan ganda. Sumbangan tersebut signifikan dengan $F$ change $=7.761$, df2 $=190$ dan Sig.F Change $=0.006$ ( sig $<0.05)$.

10. Variabel forgiveness memberikan sumbangan sebesar $0.1 \%$ dalam varian subjective well being pada wanita yang berperan ganda. Sumbangan tersebut tidak signifikan dengan $\mathrm{F}$ change $=0.170$, df2 $=189$ dan Sig. $F$ Change $=$ 0.681 ( $\operatorname{sig}>0.05$ ).

11. Variabel private religious practice memberikan sumbangan sebesar $0.2 \%$ dalam varian subjective well being pada wanita yang berperan ganda. Sumbangan tersebut tidak signifikan dengan $\mathrm{F}$ change $=0.442$, df2 $=188$ dan Sig. $\mathrm{F}$ Change $=0.507$ ( $\operatorname{sig}>0.05)$.

12. Variabel religious coping memberikan sumbangan sebesar $4.3 \%$ dalam varian subjective well being pada wanita yang berperan ganda. Sumbangan tersebut signifikan dengan $F$ change $=11.359, \mathrm{df2}=187$ dan Sig. $\mathrm{F}$ Change $=0.001(\mathrm{sig}$ $<0.05$ ). 
13. Variabel religious support memberikan sumbangan sebesar $0.8 \%$ dalam varian subjective well being pada wanita yang berperan ganda. Sumbangan tersebut tidak signifikan dengan $\mathrm{F}$ change $=2.186$, df2 $=186$ dan Sig. $F$ Change $=$ 0.141 ( $\operatorname{sig}>0.05)$.

94 
14. Variabel religious/ spiritual history memberikan sumbangan sebesar $3.0 \%$ dalam varian subjective well being pada wanita yang berperan ganda. Sumbangan tersebut signifikan dengan $\mathrm{F}$ change $=8.325$, df2 $=185$ dan Sig. $F$ Change $=0.004(\operatorname{sig}<0.05)$.

15. Variabel commitment memberikan sumbangan sebesar $0.5 \%$ dalam varian subjective well being pada wanita yang berperan ganda. Sumbangan tersebut tidak signifikan dengan $\mathrm{F}$ change $=1.417, \mathrm{df} 2=184$ dan Sig. $\mathrm{F}$ Change $=$ 0.235 ( $\operatorname{sig}>0.05)$.

16. Variabel organizational religiousnes memberikan sumbangan sebesar $5.3 \%$ dalam varian subjective well being pada wanita yang berperan ganda. Sumbangan tersebut signifikan dengan $\mathrm{F}$ change $=15.657$, df2 $=183$ dan Sig.F Change $=0.000($ sig $<0.05)$.

17. Variabel religious preference memberikan sumbangan sebesar $0.3 \%$ dalam varian subjective well being pada wanita yang berperan ganda. Sumbangan tersebut tidak signifikan dengan $\mathrm{F}$ change $=0.743$, df2 $=182$ dan Sig. $F$ Change $=0.390($ sig $>0.05)$.

Dengan demikian, terdapat tujuh dari tujuhbelas IV, yaitu conscientiousness, openess to experiences, daily spiritual experience, belief, religious coping, religious/ spiritual history dan organizational religiousness yang memberikan proporsi varian terhadap subjective well being pada wanita yang berperan ganda secara signifikan jika dilihat dari besarnya $R^{2}$ yang dihasilkan dari sumbangan proporsi variabel yang diberikan.

Berdasarkan uji hipotesis mayor yang dilakukan, maka dapat disimpulkan hasil dari penelitian ini bahwa terdapat pengaruh yang signifikan antara kepribadian dan religiusitas terhadap subjective well being pada wanita yang berperan ganda.

\section{DISKUSI}

Berdasarkan hasil penelitian dan pengujian hipotesis, didapatkan bahwa terdapat pengaruh yang signifikan dari variabel tipe kepribadian dan religiusitas terhadap subjective well being wanita berperan ganda. Hal ini sesuai dengan Diener et al. (1999) yang menyatakan bahwa terdapat hubungan 
antara subjective well being dengan kepribadian, religiusitas, dukungan sosial, dukungan keuangan, aktivitas fisik, kesehatan, usia, pendidikan, dan kecerdasan.

9 
Hasil penelitian ini menyatakan tipe kepribadian berpengaruh secara signifikan terhadap subjective well being wanita yang berperan ganda, khususnya variabel agreebleness, extraversion, dan conscientiousness. Hal ini karena tipe kepribadian memberi warna tertentu bagaimana individu menerima kejadian - kejadian dalam hidup mereka dan menjalani hidup dalam sikap yang positif atau sikap negatif (DeNeve \& Cooper, 1998).

Berdasarkan hasil penelitian sebelumnya yang mengatakan bahwa agreebleness, conscientiousness, dan openess to experience mempengaruhi subjective well being. Hubungan yang positif antara agreeableness, conscientiousness, dan openess to experience dengan subjective well being juga ditunjukkan hasil penelitian McCrae dan Costa (1991). Dan hasil penelitian ini juga menunjukkan hal yang senada, yaitu bahwa agreebleness, conscientiousness, dan openess to experience memiliki pengaruh yang lebih besar dibandingkan dengan extraversion dan neuroticism.

Hasil penelitian ini sesuai dengan penelitian sebelumnya, agreebleness, conscientiousness, dan openess to experience didapatkan selalu berhubungan dengan subjective well being (DeNeve \& Cooper, 1998) termasuk dalam penelitian ini. Hal yang senada juga diungkapkan Diener dan Lucas (1999) yang menyimpulkan bahwa agreebleness, conscientiousness, dan openess to experience merupakan prediktor subjective well being yang konsisten di Amerika Serikat. Hasil yang berbeda ditunjukkan penelitian yang dilakukan oleh Siedlecki et al. (2013). Siedlecki et al. (2013) mengatakan bahwa conscientiousness, agreeableness dan openess tidak berhubungan secara signifikan dengan subjective well-being.

Menurut penulis perbedaan hasil ini bisa disebabkan jumlah dan varians dari kondisi sampel. Penelitian - penelitian sebelumnya menggunakan sampel dengan jumlah ribuan dan dengan kondisi yang normal, sedangkan dalam penelitian ini hanya menggunakan sampel sebanyak 200 orang dan dengan sampel yang mempunyai kondisi sedikit berbeda dari kebanyakan orang.

Religiusitas dalam penelitian ini dinyatakan berpengaruh secara signifikan terhadap subjective well being wanita yang berperan ganda, khususnya dimensi private religious practice, religious/ spiritual history, dan organizational religiousness. Hal ini sejalan dengan penelitian Lufana (2010) serta penelitian Gull 
dan Dawood (2013) menyatakan bahwa religiusitas secara signifikan berkorelasi positif dengan subjective well-being, mempengaruhi subjective well-being, serta orang beragama mempunyai subjective well-being yang lebih tinggi dibandingkan orang yang tidak

96 
beragama. Khalek (2007) juga menyebutkan bahwa religiusitas pada wanita muslim di Algeria berhubungan positif dengan subjective well being, dan berkorelasi negatif dengan kecemasan dan sikap pesimis.

Dalam hasil penelitian ini variable daily spiritual experience, religion meaning, value, belief, forgiveness, religious coping, religious support, commitment, dan religious preference tidak mempunyai pengaruh terhadap subjective well being wanita yang berperan ganda. Hal ini berbeda dari hasil penelitian Josi (2008) yang menujukkan bahwa belief (keyakinan) dalam agama berperan penting pada subjective well being dan kesehatan psikologis. Agama dapat menyediakan harapan ketika seseorang putus asa, keyakinan agama merupakan sumber pengalaman kedamaian yang begitu dalam ketika seseorang mengalami distress. Keyakinan agama juga memberikan kebahagiaan, kepercayaan diri, dan menyediakan tujuan hidup, serta menganjurkan untuk memaafkan dan berpikir positif.

Hasil penelitian yang mengungkapkan hal sebaliknya dari hasil penelitian ini ditemukan pada penelitian Brown dan Tierney (2006). Penelitian yang dilakukan oleh Brown dan Tierney (2006), menemukan hubungan negatif yang kuat antara partisipasi religiusitas terhadap subjective well being. Dan hal tersebut berseberangan dengan hasil penelitian ini yang menemukan bahwa religiusitas berpengaruh positif terhadap subjective well being.

Pada penelitian ini ternyata pengaruh keseluruhan IV (tipe kepribadian dan religiusitas) terhadap DV (subjective well being) wanita yang berperan ganda hanya $38.6 \%$. Hal ini membuktikan bahwa masih banyak hal lain di luar penelitian ini yang ikut mempengaruhi subjective well being wanita yang berperan ganda. Yang demikian bisa terjadi karena dalam penelitian ini hanya diteliti dua IV saja, sehingga variabel lain yang mungkin ikut berpengaruh tidak ikut diteliti, seperti tingkat pendidikan dan pendapatan. Individu yang berpendidikan tinggi tentu memiliki subjective well being yang berbeda dengan individu yang berpendidikan rendah. Dan tingkat subjective well being individu yang memiliki pendapatan tinggi tentu berbeda dengan individu yang memiliki pendapatan rendah.

Adapun saran dari penelitian ini adalah: 
1. Pada penelitian ini, sampel yang digunakan hanya wanita berperan ganda yang bersuami dan yang tidak bersuami di daerah Jakarta Utara dan Jakarta Pusat dengan tingkat sosial dan ekonomi menengah ke bawah. Dan kebanyakan responden dalam penelitian ini bekerja sebagai karyawati dan guru. Oleh karena itu, pada penelitian 
selanjutnya disarankan agar menambahkan gradasi jenis pekerjaan dan tingkat pendapatan menengah ke atas atau tingkat sosial dan ekonomi menengah ke atas.

2. Pada penelitian selanjutnya, diharapkan menambah variabel lain yang mempengaruhi subjective well being wanita yang berperan ganda, mengingat hasil penelitian ini menemukan bahwa $61,4 \%$ variabel lain yang memberikan sumbangan bagi bervariasinya subjective well being wanita yang berperan ganda. Selain itu, diharapkan pula untuk menambah variabel kategorik lainnya agar lebih memperluas gambaran penelitian.

3. Pada penelitian selanjutnya disarankan untuk tidak menggunakan teori religiusitas Fetzer, dikarenakan dimensi dalam teori ini hampir mirip antara satu dengan lainnya, sehingga agak menyulitkan pengklasifikasian. Dan diajurkan untuk menggunakan teori religiusitas Glock dan Stark, karena teori itu Dan penelitian selanjutnya juga disarankan untuk meneliti dimensi religiusitas apa saja yang selalu terbukti mempengaruhi subjective well being, dan dimensi apa saja yang selalu tidak terbukti mempengaruhi subjective well being.

4. Pada penelitian ini ditemukan bahwa ada pengaruh dari kepribadian dan religiusitas terhadap subjective well being wanita yang berperan ganda. Selanjutnya agar dipertimbangkan oleh orang-orang terdekat wanita yang berperan ganda, seperti orangtua, suami, anak, ataupun teman dalam menumbuhkan subjective well being dengan memperhatikan aspek-aspek yang tadi telah disebutkan, misalnya dengan memberikan perhatian dan nasihat keagamaan, mendengarkan dan membantu wanita yang berperan ganda saat menghadapi masalah. Bagi para wanita yang berperan ganda juga disarankan untuk bergabung dalam komunitas atau organisasi. Hal ini dapat menjadi tempat mencari sahabat baru, bertukar pikiran dan menambah wawasan.

\section{DAFTAR PUSTAKA}

Abeles, R, et. al. (1999). Multidimensional measurement of religiousness/ spirituality for use in health research: $A$ Report of the Fetzer Institute/ National Institute on Aging Working Group. Kalamazoo: MI: Fetzer Institute. 
Aldert, M. (2003). Effects of religion and purpose in life on elders" subjective well-being and attitudes toward death. Journal of Religious Gerontology, 14 (4). doi:10.1300/J078v14n04_04.

98 
Brown \& Tierney. (2006). Religion and Subjective well-being Among China"s Elderly Population. Goldfarb Center Working Paper, 007-038.

DeNeve, K., \& Cooper, H. (1998). The happy personality: A meta-analysis of 137 personality traits and subjective wellbeing. Psychological Bulletin, 124 (2), 197-229.

Diener, E. (2005). Guidelines for National indicators of subjective well-being and ill-being. Positive Psychology Center. University of Pennyslvania.

Diener, E. (1984). Subjective well-being. Psychological Bulletin, 95 (3), 542-575.

Diener, E. (2013). The remarkable changes in the science of subjective well-being. Journal of Perspectives on Psychological Science, 10 (2), 321- 345.

Diener, E., Emmons, R.A., Larsen, R.J., \& Griffin, S. (1985). The satisfaction with life scale. Journal of Personality Assessment, 49 (1), 203-235.

Diener, E., \& Larsen, R. J. (1984). Temporal stability and crosssituational consistency of affective, behavioral, and cognitive responses. Journal of Personality and Social Psychology, 47 (4), 871-883.

Diener, E., Suh, E.M., Lucas, R.E., \& Smith, H.L. (1999). Subjective well-being: Three decades of progress. Psychological Bulletin, 125 (2), 276-302.

Diener, E., Tay, L., \& Myers, D.G. (2011). The religion paradox: If religion makes people happy, why are so many dropping out?. Journal of Personality and Social Psychology, 101 (6), 1278-1290. doi: 10.1037/a0024402.

Feist, J., \& Feist, G.J. (2010). Theories of personality, 7th ed. teori kepribadian, edisi 7, buku 2. Smita Prahita Sjahrini (Terj). Jakarta: Penerbit Salemba Humanika.

Goldberg. (1992). Possible questionnaire format for administrating the 100-item set of IPIP big-five factors makers. Journal of Psychology. Diunduh tanggal 17 Juni 2014, dari http://ipip.ori.org/new_ipip_100 item_scale.htm

Gutierrez, J.L., Jimenez, B.M., Hernandez, E.G., \& Puente, C.P. (2005). Personality and subjective well-being: big five correlates and demographic variables. Personality and Individual Differences, 38, 1561-1569. doi: 10.1016/j.paid.2004.09.015.

Lufanna, C.H. (2010). Religiosity and subjective wellbeing in christianity, buddhism and taoism. Thesis. Deakin University.

Pavot, W., \& Diener, E. (2009). Review of the satisfaction with life scale. Social Indicator Research Series, 39 (1). doi:10.1007/978-90-481-2354-4_5.

Pervin, L.A., Cervone, D., \& John, O.P. (2010). Personality: 
research, 9th ed. Psikologi kepribadian: Teori dan penelitian, edisi ke-9.

A.K. Anwar (terj). Jakarta: Kencana.

9

9 
Watson, D., Clark, L.A., \& Tellegen, A. (1988). Development and validation of brief measure of positive and negative affect: The PANAS scales. Journal of Personality and Social Psychology, 54 (6), 1063-1070. 